\title{
Sambucus nigra (black elder) as alternative treatment for cold and flu
}

\author{
Mohaddese Mahboubi ${ }^{1}$ (1)
}

Received: 15 February 2020 / Accepted: 9 June 2020 / Published online: 10 July 2020

(c) Institute of Korean Medicine, Kyung Hee University 2020

\begin{abstract}
Common cold and flu are caused by common respiratory viral pathogens, which results in hospitalization and death in the world. Among the viral infections, influenza viruses have worldwide spread with major effects on health of societies. Change in antigenic structures of influenza viruses is associated with the lack of effective treatments. Therefore, the use of herbal medicine as alternative choice can be used for management of flu and cold. The flowers of Sambucus nigra or black elders have been approved by commission E for cold, and flu. Although, elders are used in different herbal formulates, but there is no comprehensive study. The subject of this review article was to summarize the efficacy of black elder in treatment of cold and flu. For preparing this manuscript, the electronic resources, books, and thesis were searched by key words of Sambucus, elder, cold, flu, and viral infections. The results of investigations exhibited that there are four clinical trials for elder berries, which it reduced the cold duration and severity (fever, pain, congestion, cough), while there is no clinical trial for elder flower on common cold and flu in spite of its approval by commission E. So, evaluating the efficacy of elder flowers in comparison with its berries and standard treatment on patients with viral respiratory infections should be the subject of large clinical studies.
\end{abstract}

Keywords Sambucus nigra $\cdot$ Elder $\cdot$ Flower $\cdot$ Berries $\cdot$ Influenza $\cdot$ Cold

\section{Introduction}

Respiratory viral infections are caused by common respiratory viral pathogens, including enterovirus, adenovirus, rhinovirus, para influenza, respiratory syncytial virus and influenza (Troy and Bosco 2016). According to the estimation of WHO (World Health Organization), the annual respiratory viral infections are 25-50 million cases in USA, which results in 150,000 hospitalizations and annual 30,000 to 40,000 death (Girard et al. 2005). Among different viral respiratory pathogens, influenza viruses have the major impact on the health of world. The changes in antigenic structures of respiratory viruses and the lack of effective treatments are associated with pulmonary complications and mortality (Moghadami 2017). In order to reduce the symptoms of diseases, the use of alternative treatments for management of influenza and influenza like illness is common among the

Mohaddese Mahboubi

mahboubi1357@yahoo.com

1 Medicinal Plants Research Department, Research and Development, TabibDaru Pharmaceutical Company, Kashan, Iran people (Mousa 2017). Among different medicinal plants, black elder or Sambucus nigra is traditionally recommended for treatment of cold, influenza and influenza like illnesses. Black elder is a flowering small tree from Caprifoliaceae family, native to Europe and North America. It has excellent edible and medicinal parts.

Although, there is a review article concerning the antiviral properties of black elder (Porter and Bode 2017), but there is no substantial review article concerning its efficacy in treatment of cold and flu. The efficacy and the mechanisms related to black elder in treatment of cold and flu illnesses was the subject of this review. First of all, the chemical composition of black elder, traditional uses of black elder were reviewed, then modern investigations and its related mechanisms on efficacy of black elder on patients with cold and flu was evaluated.

\section{Black elder and its chemical composition}

Among different members of Sambucus species, FDA approved S. canadensis and S. nigra flowers as generally Recognized as Safe (GRAS) for use as flavoring agent. 
Elders, especially Sambucus nigra is natively spread in European countries and is used as colorant or flavor in Juices and wines (Atkinson and Atkinson 2002). Among different parts of Sambucus nigra, its flowers and berries are considered as medicinal parts, while elder flowers have been approved by German commission E for colds, while berries, leaves and barks are lack of approval by WHO, ESCOP, and German Commission E (Ulbricht et al. 2014). The potentially toxic cyanogenic glycoside "sambunigrin" is present in barks, leaves, seeds and unripe fruits. The amount of cyanogenic glycoside depends on growing conditions and the flowers have lower content of cyanogenic glycoside in comparison with other parts of plant (Senica et al. 2017). Cyanogenic glycosides are hydrolyzed in the gastrointestinal tract to hydrogen cyanide (Vlachojannis et al. 2010). Due to the importance of elder berries and flowers, their chemical compositions were investigated (Fig. 1).

The elder flowers are a composition of free aglycones (Kaempferol, quercetin), flavonol glycosides (hyposide, astragalin, isoquercitrin, rutin), phenolic compounds (chlorogenic acids), sterols, triterpenes ( $\alpha$-, $\beta$-amyrin), triterpene acids (ursolic acid, oleanolic acid), free fatty acids, alkanes, tannins, mucilage and sugar. Elder flowers are rich of N-phenylpropenoyl-l-amino acid amides (Hensel et al. 2007), which strongly stimulated the mitochondrial activity and cell proliferation of human keratinocytes and liver cells and deduced the adhesion of Helicobacter pylori to the human stomach without any necrotic toxicity effects (Hensel et al. 2007).

Anthocyanins (cyanidin-3-glucoside, cyanidin-3-sambubioside, cyanidin-3-sambubioside-5-glucoside, cyanidin3,5-diglucoside), ascorbic acid and quercetin were isolated from elder berries (Kaack and Austed 1998). Cyanidin3 -glucoside and cyanidin-3-sambubioside are present in elderberries at percent of 65.7 and 32.4 of total anthocyanins (Brønnum-Hansen and Honoré Hansen 1983). Elderberries are containing the low amount of essential oil (0.01) (Knudsen and Kaack 2015). Thirty-four components were identified the elderberry essential oil, extracted by microdistillation, which representing $86.1 \%$ of total oil composition. Phenylacetaldehyde (32.3\%), benzaldehyde (7.9\%), ethyl linoleate (5.4\%), 4-vinyl guaiacol (4.9\%), linalool (4.5\%), and phenyl ethyl alcohol (4.1\%) were the main components of elderberry essential oil (Duymus Agalar et al. 2014). Fruit ripening process can influence on the content of anthocyanin, soluble solid, and titratable acid (Rodrigues et al. 2018). The aroma characteristic of elderberries is used in different formulations. Aliphatic esters ((E)- $\beta$ damascenone, 2-phenyl ethanol, phenylacetaldehyde, dihydroedulan, ethyl-9-decenoate, and nonanal) are responsible for fruity sweet characteristic aroma of elderberries (Kaack 2008). The presence of cyanidin-3-glucoside and cyanidin3 -sambubioside is responsible for dark color of European elder berries (Mateus et al. 2004). Chemical composition of elder berries and flowers exhibited the presence of a number of health promoting compounds (Vlachojannis et al. 2010), which makes it as favorite supplements.

\section{Black elder in traditional medicine}

Black elder tree has been popular plant from ancient times. Russian believe that elder tree drives away the evil spirits and takes away the fevers. Hanging the elder branches on the doors and windows are believed to drive away witches and evils. In traditional medicine, elder fruits and flowers are known most often medicinal parts of plant. Black elder is one important medicinal plant in Germany, which its flowers are used as diaphoretic agent for feverish common colds (Bradley 1992). Black elder flowers are used for treatment of scarlatina and fever (Kaur et al. 2014).

Dried elder flowers have strong odor with sweet taste to slightly bitter and are used as diaphoretic agent in pharmacopoeias and international systems for reducing the fever and chills (Organization 2004). Elder flowers are used for treatment of conjunctivitis, constipation, diabetes, diarrhea, dry skin, headaches and rheumatism in folk medicine (Organization 2004). In Germany and United states, elder flowers are used for flu and cold in dosage form of tea, coated tablets, and fluid extracts. In United States, and Canada, elder flowers with peppermint leaf and yarrow flowers are used to relieve the fever related to colds. Elder flowers are used as diuretic in France and Belgium (Wichtl and Bisset 1994). Native Americans use elder flowers for infections, and coughs. The mixture of elder flowers with honey as the gargle is used for coughs, head colds, and flu. The mixture of peppermint, honey and elder flower is used to enhance the diaphoresis and colds (Ulbricht et al. 2014). The diaphoretic effects of elder flowers are related to flavonoids and phenolic acids content (Wichtl and Bisset 1994). Elder flowers were used by ancient Egyptians to heal the burns and improve the complexion.

The use of elder flowers for cold is approved by German Commission E (Blumenthal et al. 2000), while berries, leaves and barks are lack of approval by WHO, ESCOP, German Commission E. Elder flowers are GRAS (Ulbricht et al. 2014) and have been approved for treatment of common cold, fever (British Herbal Pharmacopoeia 1966) and catarrh (Blumenthal 1998), and as diuretic by British Herbal Compendium (British Herbal Pharmacopoeia 1966) and German Commission E (Blumenthal 1998). Dried ripe or fresh elderberry are used for constipation, neuropathic pain, headache and toothache in Traditional German medicine (Hänsel et al. 1994). There are some evidences for efficacy of elder flowers in treatment of cold and fever more than elderberries, although elderberries are used for pain and fever. Therefore, 
Fig. 1 The chemical composition of main component of black elder (Sambucus nigra)<smiles>O=c1c(O)c(-c2ccc(O)cc2)oc2cc(O)cc(O)c12</smiles>

KAEMPFEROL

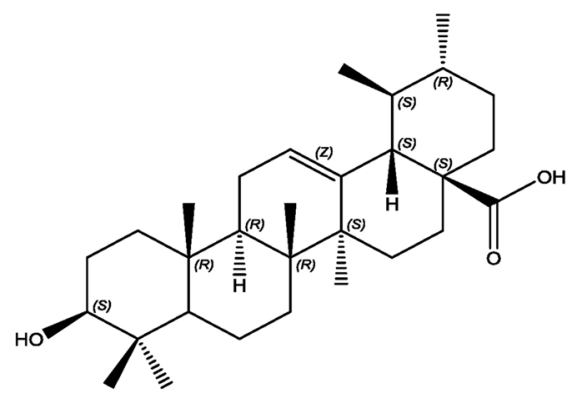

URSOLIC ACID

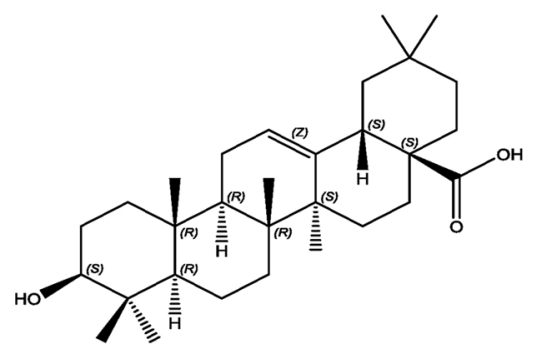

OLEANOLICACID<smiles></smiles>

CYANIDIN-3-GLUCOSIDE

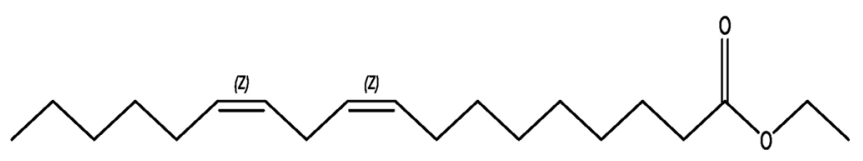

ETHYL LINOLEATE<smiles>O=Cc1ccccc1</smiles>

BENZALDEHYDE<smiles>O=c1c(O)c(-c2ccc(O)c(O)c2)oc2cc(O)cc(O)c12</smiles>

QUERCETIN<smiles>O=C1O[C@H]([C@@H](O)CO)C(O)=C1O</smiles>

ASCORBICACID<smiles>O=CCc1ccccc1</smiles>

PHENYLACETALDEHYDE<smiles>O=Cc1ccccc1</smiles>

BENZALDEHYDE 
it is important to confirm the efficacy of elder flowers and berries on cold and flu, in modern medicine.

\section{The efficacy of black elder in treatment of respiratory viral infections}

\section{The in vitro antiviral effects of black elder}

The antiviral activities of black elder berries and flowers were the subject of some investigations in the literatures. Elderberries inhibited the HIV isolates in CD4-I cell lines and peripheral blood lymphocytes (Sahpira-Nahor et al. 1995). Incubation of HIV strains with elderberry extract significantly reduced the infectivity of HIV strains. The antiviral effects of elderberries extract were confirmed against several human strains of type $\mathrm{A}\left(\mathrm{H}_{3} \mathrm{~N}_{2}, \mathrm{H}_{1} \mathrm{~N}_{1}, \mathrm{H}_{3} \mathrm{~N}_{2}, \mathrm{H}_{1} \mathrm{~N}_{1}\right)$ and influenza virus type $\mathrm{B}$ (Zakay-Rones et al. 1995). Elderberry extract inhibited the Human influenza A $\left(\mathrm{H}_{1} \mathrm{~N}_{1}\right)$ with $\mathrm{IC}_{50}$ of $252 \pm 34 \mu \mathrm{g} / \mathrm{mL}$ (Roschek et al. 2009), the propagation of human pathogenic influenza viruses in cats (Krawitz et al. 2011), and immunodeficiency virus (FIV) (Uncini Manganelli et al. 2005). In other study, elderberries had antiviral activity against influenza A, influenza B, HIV, Herpes simplex-1 viruses, and pathogenic chicken coronavirus (Barak et al. 2001; Morag et al. 1997; Chen et al. 2014). Administration of elderberries with olive leaf extract significantly reduced the viral load from 17,000 to 4000 in HIV positive woman (Konlee 1998). Elderberry extract inhibited the viral hemagglutinin for several strains of influenza viruses in cell culture media. Elderberry extract inhibited the hemagglutinin by binding to the virus and inhibit its attachment to glycol-conjugate receptors on the erythrocytes. Elderberry extract inhibited the replication of human and animal influenza viruses. Hemagglutinin mediates the attachment of virus to salic acid residues in glycol-conjugate receptors on host cells membranes. Elderberry extract blocked the viral salidase of influenza virus (Zakay-Rones et al. 1995).

In addition to antiviral activity of elder berries extract, the antiviral activity of elder flowers were confirmed. Elder flowers and leaves methanol extract had antiviral activity against dengue virus serotype-2 $(400 \mu \mathrm{g} / \mathrm{mL})$ (Castillo-Maldonado et al. 2017). A yellow lyophilized powder (SHS174) hot infusion extract of ground, air-dried elder flowers, Hypericum perforatum aerial parts, and Saponaria oficinalis $(100 \mathrm{~g} ; 70 \mathrm{~g} ; 40 \mathrm{~g})$ had anti-viral activity against influenza and herpes simplex virus type 1 (Serkedjieva et al. 1990).

The antiviral activities of elder berries and elder flowers are related to flavonoid contents. The antiviral effects of pure flavonoids were confirmed against herpes simplex virus type 1, Para-influenza, influenza, and respiratory syncytial virus (Mahmood et al. 1993; Nagai et al. 1992).
Cyanidin 3-glucoside and cyanidin 3-sambubioside as the main anthocyanins of elder exhibited the antiviral effects. Flavonoids (5,7,30,40-tetra-O-methylquercetin and 5,7-dihydroxy-4-oxo-2-(3,4,5-trihydroxyphenyl)chroman-3-yl-3,4,5tri hydroxyl cyclo hexane carboxylate) are attached to $\mathrm{H}_{1} \mathrm{~N}_{1}$ virions. The $\mathrm{IC}_{50}$ for 5,7,30,40-tetra-O-methylquercetin and dihydromyricetin were 0.36 and $8.7 \mu \mathrm{M}$ against $\mathrm{H}_{1} \mathrm{~N}_{1}$ infections and were comparable with oseltamivir (Tamiflu; $0.32 \mu \mathrm{M})$ and amantadine $(27 \mu \mathrm{M})$ (Roschek et al. 2009). During the spread of Influenza viral infections, the secondary infections by bacteria can lead to severe pneumonia. Elderberry extracts (standard to minimum concentration of $3.2 \%$ anthocyanin) decreased the populations of Streptococcus pyogenes (groups $\mathrm{C}, \mathrm{G}$ ) and Branhamella catarrhalis more than 70\% (Krawitz et al. 2011). The results of experimental studies confirmed the antiviral and antibacterial activities of elder flowers and elderberries against viral and bacterial respiratory infections, which are related to their flavonoid contents.

\section{Clinical trials on efficacy of black elder in viral infections}

In $400 \mathrm{BCE}$, elder tree is regarded as a medicine for chest. Elderberry extract was a prophylactic treatment for influenza like diseases and there is one report of animal study for treatment of influenza like symptoms in a colony of chimpanzees (Burge et al. 1999).

Commercial products from elder berries extracts are standardized on the base of flavonoids, flavonols and flavones and the major studies were performed on standard elderberries extracts.

There is four properly randomized clinical trials and statistically good scientific evidence of elder efficacy against influenza and influenza like diseases (Ulbricht et al. 2014). Forty infected patients (5-50 years old) with at least three symptoms of flu including "fever higher than $38^{\circ} \mathrm{C}$, myalgia, nasal discharge, and cough" were included in a double blind clinical study. The efficacy of standardized elder berries extract was evaluated on duration of influenza in these patients in comparison with placebo groups. The patients were recommended to use 2-4 teaspoons of syrups containing standardized elder berries extract or placebo for 3 days. The clinical symptoms of headache, fever, rhinitis, pharyngitis, malaise, cough, fatigue, and myalgia were recorded in patients of two groups over a period of 6 days and finally the feeling of improvement or complete cure were recorded. The presence of anti-bodies to influenza A and B, Respiratory syncytial virus (RSV) and adenoviruses were evaluated in two groups of patients. The results of experimental evaluations exhibited that the elderberry berries extract dose dependently inhibited the replication of influenza viruses. At the baseline, the patients complained of headache, fever, 
myalgia, malaise, fatigue, and rhinitis patients and rarely cough. The fever's persistence was 4 and 6 days in elderberry extract and placebo groups, respectively. The average days of fever were 2.36 and 3.33 in elderberry extract and placebo groups, respectively. After 3 days of treatment, the clinical symptoms of flu were decreased in $73.3 \%$ and $33.3 \%$ of elderberry extract and placebo groups. After 2 days, the clinical symptoms were completely cured in $40 \%$ and $16.7 \%$ of patients from elderberry and placebo groups. The corresponding complete cure reached to $86.7 \%$ and $33.4 \%$, after 3 days of treatments, respectively. After 5 days of treatment with placebo, $41.7 \%$ of patients were completely cured. The averages duration of flu were 2.7 and 4 days in elderberry extract and placebo groups, respectively. Therefore, treatment of patients $(n=15)$ with elderberry extract for 3 days improved the clinical symptoms of flu in $93.3 \%$ and $91.7 \%$ of patients after 2 and 6 days. $90 \%$ of patients were completely improved in elderberry extract after 2 days of intervention, but the complete cure was happen in placebo group after 6 days. Elderberry extract enhanced the immune response in patients, so, the hemagglutinin antibody titers for influenza $B$ increased in elderberry group higher than that of placebo group. The treatments were tolerated and no adverse effects were recorded in patients, who received 4 teaspoons of elderberry extract syrup, daily for 3 days (Zakay-Rones et al. 1995).

In second multicenter randomized placebo controlled trial, the efficacy and safety of standardized elderberry extract was evaluated in patients (16-54 years old) with influenza $\mathrm{A}$ and $\mathrm{B}$ infections $(n=30)$, in comparison with placebo group $(n=30)$. The patients of this study had fever higher than $38{ }^{\circ} \mathrm{C}$ with at least one clinical symptom of influenza. The patients of each group received $15 \mathrm{~mL}$ of elderberry or placebo syrups, four times a day for 5 continuous days. For evaluating the efficacy of treatment, the influenza symptoms (aches, pains, degree and frequency of coughing, mucus discharge, and the quality of sleep), Visual Analogue Scales (VAS), and overall well-being scores were recorded before and after treatment. At the baseline, there was no significant difference between two groups in regard of demographic status, clinical symptoms, VAS scores and the average duration of clinical symptoms. The majority of patients $(90 \%)$ were improved in elderberry groups after $3-4$ days $(3.1 \pm 1.3)$ of treatment, while the corresponding improvement was $7-8$ days $(7.1 \pm 2.5)$ for placebo group $(p<0.001)$. The use of ancillary therapies was significantly less in the elderberry group compared with placebo group. The elderberry syrup is effective against influenza A virus, more than influenza B type, without any adverse effects (Zakay-Rones et al. 2004). As the results of clinical study showed a significant reduction (3-4 days) was observed for duration of flu in elderberry syrup in comparison with placebo group.
In other double-blind, placebo-controlled study, the efficacy of elderberry extract (175 mg extract) in the form of lozenges was compared with placebo on 64 patients (16-60 years old) with flu like symptoms. The patients were recommended daily to use four lozenges for 2 days. The self-assessment and the improvement on clinical symptoms of fever, headache, muscle aches, cough, mucus discharge from the respiratory tract, and nasal congestion on the VAS scores were evaluated four times a day during 2-days of treatment. At the base line, $46.9 \%$ and $28.1 \%$ of patients in elderberry and placebo groups had fever $\left(37.3-38.8^{\circ} \mathrm{C}\right)$. After 2 days consumption of elderberry lozenges, the means of VAS score for fever significantly reduced from $2.67 \pm 1.8$ to $0.47 \pm 0.64(p<0.0001)$. All patients had the headache at the beginning of study. The VAS scores for headache significantly reduced from $4.47 \pm 2.14$ to $1.53 \pm 1.41$ and $0.28 \pm 0.63$ after 24 and $48 \mathrm{~h}$. The patients with no and mild headache were $78 \%$ and $22 \%$, respectively. In placebo group, the VAS scores for headache increased from $3.78 \pm 1.66$ to $5.25 \pm 1.34$ over 48 h. $96.9 \%$ and $93.8 \%$ of the patients had muscle aches in elderberry and placebo groups, respectively. In elderberry group, $87 \%$ of patients were free of pain after $48 \mathrm{~h}(2.87 \pm 2.13$ to $0.16 \pm 0.45)$ of treatment, while the VAS scores for placebo group increased from $2.13 \pm 2.1$ to $3.47 \pm 1.50$ after $48 \mathrm{~h}$. The prevalence of nasal congestions was $100 \%$ and $87.5 \%$ in elderberry and placebo groups. After 24 and $48 \mathrm{~h}$ consumption of elderberry lozenges, the VAS score for nasal congestion significantly reduced from $4.03 \pm 2.1$ to $1.47 \pm 1.14$ and $0.56 \pm 0.62$, respectively. The Vas score for nasal congestion significantly increased from $3.3 \pm 1.71$ to $4.26 \pm 1.81$ in placebo group $(p<0.05)$. The nasal mucus discharges were prevalent in only $50 \%$ and $34.3 \%$ of patients in elderberry and placebo groups, respectively. After $24 \mathrm{~h}$ of treatment with elderberry extract, VAS score exhibited insignificant improvement $(p=0.26)$ in nasal mucus discharge, while after 48 of treatment with elderberry lozenges, a significant reduction $(\mathrm{p}=0.0019)$ in VAS score from $1.49 \pm 1.61$ to $0.5 \pm 0.52$ for nasal mucus discharge was observed. Only one patient in placebo group (6\%) had an improvement in nasal mucus discharge. After $48 \mathrm{~h}$ of treatment with elderberry, cough relieved in $31 \%$ of patients, and $37 \%$ of patients had an improvement in cough with VAS score about one. The VAS score for cough increased from $2.19 \pm 1.47$ to $3.69 \pm 1.25$ in placebo group. No adverse effects related to elderberry or placebo were reported during the study (Kong 2009). Elderberry lozenges significantly improved fever; headache, muscle aches and nasal congestion during $24 \mathrm{~h}$ of treatment, while the cough and mucus discharge improved during $48 \mathrm{~h}$ of treatment.

The preventive effects of $300 \mathrm{mg}$ standard elderberry extract $(n=158)$ in the form of capsule were the subject of double blind placebo $(n=154)$ controlled clinical trial including 312 passengers of economy class, and its effects 
on respiratory and mental health were evaluated. Jackson scores were used to evaluate the daily cold duration, cold episode and cold clinical symptoms. The volunteers completed the questionnaires regarding upper respiratory systems, and quality of life before and after travel. The volunteers took two capsules of elderberries $(600 \mathrm{mg})$ or placebo, 10 days before the travel. Then, the treatments were continued by three capsules $(900 \mathrm{mg}$ ) from one day before travel until 5 days after arriving at destination. The percentage of taken capsules against total administered capsules was used as compliance of study. At the base line, the prevalence of cold episode were insignificant $(p=0.4)$ and were 17 and 12 in placebo and elderberry groups, respectively. Travelling increased the prevalence of respiratory symptoms in two groups, but the consumption of elderberry extract improved the physical health of volunteers during the clinical study, while showed a decline in physical health of placebo group. The volunteers in placebo group had significant long cold episode $(\mathrm{p}=0.05)$. Elderberries extract significantly reduced the cold duration ( 4.75 vs. 6.88 days) and cold severity (21 vs. 34) in treated passengers. Elderberry capsules had no significant effect on mental health of participants. No adverse effects were reported for standard elderberry extract during the study (Tiralongo et al. 2016).

The results of four clinical studies were the subject of a meta-analysis $(n=180)$, which administration of elderberry extract $(n=89)$ in comparison with control group $(n=91)$ significantly reduced the clinical respiratory symptoms in patients with influenza, and common cold and the efficacy of elderberry extract against influenza viral infections was higher than that of common cold. Elderberry extract had no overall effect on flu vaccination and the effects of elderberry extract on upper respiratory symptoms of patients with and without flu vaccination were the same. No adverse or sedative effects were reported for elderberry extract during the study, and one complaint for taste of elderberry syrup was reported (Roschek et al. 2009).

The clinical studies (Table 1) confirmed the efficacy of standard elderberry extract in reduction of cold and influenza duration and improvement of their clinical symptoms. Although, German commission E approved the application of elder flowers in treatment of cold and flu, but there is no clinical study for elder flower in treatment of flu, cold or viral respiratory infections.

Table 1 The clinical studies on elderberries extract in treatment of flu like symptoms

\begin{tabular}{|c|c|c|c|c|}
\hline Treatment group & Clinical symptoms & Dose & Efficacy & Adverse effect \\
\hline $\begin{array}{l}\text { Sambucol Placebo (Zakay- } \\
\text { Rones et al. 1995) }\end{array}$ & $\begin{array}{l}40 \text { patients ( } 5-50 \text { years old }) \\
\text { with cold }\end{array}$ & $2-4$ teaspoons for 3 days & $\begin{array}{l}\downarrow \text { Means numbers of day with } \\
\text { fever ( } 2.36 \text { vs. } 3.33 \text { days) } \\
\uparrow \text { Improvement in clinical } \\
\text { symptoms } \\
\uparrow \text { Complete cure after } 2 \text { days } \\
\text { (40\% vs. } 16.7 \%) \\
\downarrow \text { Mean duration of illness } \\
\text { (2.7 vs. } 4 \text { days) } \\
\uparrow \text { Improvement the symptoms } \\
\text { of flu and fever (93.3\% } \\
\text { during } 2 \text { vs. } 91.7 \% \text { during } \\
6 \text { days) }\end{array}$ & No adverse effect \\
\hline $\begin{array}{l}\text { Sambucol Placebo (Zakay- } \\
\text { Rones et al. 2004) }\end{array}$ & $\begin{array}{l}60 \text { patients }(16-54 \text { years old }) \\
\text { with influenza A and B }\end{array}$ & $\begin{array}{l}15 \mathrm{~mL} \text { treatments four times } \\
\text { a day for } 5 \text { days }\end{array}$ & $\begin{array}{l}\text { Improvement in clini- } \\
\text { cal symptoms ( } 3-4 \text { vs. } \\
7-8 \text { days) } \\
\text { in global evaluation scores } \\
\quad(3.1 \pm 1.3 \text { vs. } 7.1 \pm 2.5 \text { days) } \\
\downarrow \text { Ancillary therapies } \\
\text { Nearly } 90 \% \text { completely treat- } \\
\text { ment ( } 2-3 \text { vs. } 6 \text { days) } \\
\downarrow \text { The duration of illness } \\
\text { (3-4 days) }\end{array}$ & No adverse effect \\
\hline $\begin{array}{l}\text { Elderberry extract placebo } \\
\text { (Tiralongo et al. 2016) }\end{array}$ & $\begin{array}{l}312 \text { passengers of economy } \\
\text { class }\end{array}$ & $\begin{array}{l}2 \text { capsules }(600 \mathrm{mg}), 10 \text { days } \\
\text { before travel and } 3 \text { capsules } \\
(900 \mathrm{mg}) \text { from } 1 \text { days } \\
\text { before travel until } 5 \text { days } \\
\text { after arriving at destination }\end{array}$ & $\begin{array}{l}\downarrow \text { Cold duration and severity } \\
\text { No effect on mental health }\end{array}$ & No adverse effects \\
\hline $\begin{array}{l}\text { Elderberry Placebo (Kong } \\
\text { 2009) }\end{array}$ & $\begin{array}{l}64 \text { patients ( } 16-60 \text { years old) } \\
\text { with }\end{array}$ & Four lozenges daily for 2 days & $\begin{array}{l}\downarrow \text { Means of VAS score for } \\
\text { fever, headache, muscle } \\
\text { aches, nasal congestion, } \\
\text { nasal mucus discharge }\end{array}$ & No adverse effects \\
\hline
\end{tabular}




\section{Mechanisms of action for elder in treatment of viral respiratory infection}

Different mechanisms may be responsible for efficacy of elder in management of flu and common cold (Fig. 2).

Hemagglutinin antigens as glycoprotein molecules allow the virus to attach to cellular sialic acid on host cell membrane and fuse to it. The dispersion of virus from infected cells is caused by neuraminidase antigens and break down the cellular sialic acids. Elderberries lectins (SA $\alpha 2,6 \mathrm{Gals}$, and particularly Neu5Ac $22,6 \mathrm{Gal}$ ) bind to sialic acids of host cell membrane and prevent the influenza virus hemagglutinin's attachment to host cells. Furthermore, elderberry 's flavonoids attach to hemagglutinin of influenza virus and prevent the viral attachment to host cell receptors (Zakay-Rones et al. 1995). The denaturalization of hemagglutinin spikes of influenza by elder extracts is associated with viral inactivation to pierce and enter the cells and replicate (Janeway et al. 2001).

The other involved mechanism, responsible for antiviral activity of elderberry in treatment of flu and cold is its immune-modulatory effects. The immune-modulatory effects of elder berries are related to anthocyanin content. The immune-modulatory effects of elderberry extracts are associated with cytokines production (cyanidin-3-glucoside and cyanidin-3-sambubioside), phagocytes activation and its immigration to inflamed tissues (Janeway et al. 2001). Elderberry extract increased the influenza viral antibody in comparison with placebo group. Incubation of blood derived monocytes with elderberry extract significantly increased the production of IL- $1 \beta$, TNF- $\alpha$, IL- 6 , IL- 8 , and TNF- $\alpha$ (Barak et al. 2001). A significant increase in inflammatory cytokine of IFN- $\gamma$ was observed after administration of elder in insulin deficiency diabetic and normal rats (Badescu et al. 2015). Furthermore, it is reported that the strong immune<smiles>[R]c1cc2c([R])c([R])c([R])cc2[o+]c1-c1cc([R])c([R7])c([R7])c1</smiles>

Anti-inflammatory effect

Anti-inflammatory
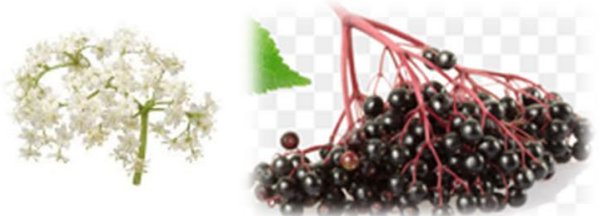

Inactivation of Influenza Viruses

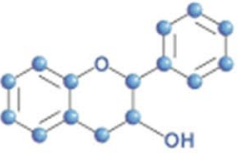

FLAVONOIDS

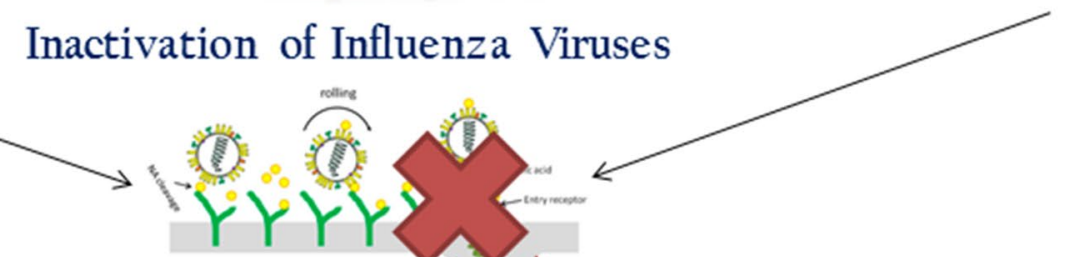<smiles>O=c1oc2c(O)c(O)cc3c(=O)oc4c(O)c(O)cc1c4c23</smiles>

Polyphenols

Antioxidant activity Anti-inflammatory effect ( $\downarrow$ Pain, fever)

\footnotetext{
$\downarrow$ fever, cough, muscle ache, headache, nasal

congestion, mucus discharge

$\uparrow$ improvement in clinical symptoms

$\uparrow$ Complete cure after 2 days

$\downarrow$ Mean duration of illness ( 2.7 days)

个Improvement the symptoms of flu
}

Fig. 2 The mechanisms of action for the efficacy of black elder in treatment of Cold and Flu 
modulatory effects of elder are related to pectic polysaccharides (Ho 2017).

Administration of elder improved the clinical symptoms of flu and common cold. Three strains of influenza (A, B, C) can be attributed to influenza. Flu infects the entire respiratory system and the onset of symptoms is sudden within a few hours. Fever higher than $101{ }^{\circ} \mathrm{F}$, headache, general aches; and pains are the characteristic symptoms of flu. Cough, chest congestion, sore throat, stuffy nose, fatigue, weakness, and extreme exhaustion are prevalent among patients (Fendrick et al. 2003). The antioxidant effects of elder extracts are responsible for their efficacy in reducing the pain, and fever. The polyphenols (Stoilova et al. 2007; Viapiana and Wesolowski 2017), and anthocyanins in elders (da Silva et al. 2019) are strongly responsible for the antioxidant activities. Elder berries are used as expectorant and mild anti-inflammatory agents in treatment of upper respiratory ailments (Blumenthal et al. 2000). The anti-inflammatory effects of anthocyanins in elder were comparable with acetylsalicylic acid (Wang et al. 1999). A reduction in mucus secretion was observed in presence of elder in laboratory studies (Ueno et al. 1997). Elder may reduce the swelling of mucus membranes and nasal congestion (Ulbricht et al. 2014). Therefore, elderberry extracts by different mechanisms reduced the aches, pain and fever during the outbreak of influenza.

\section{Safety and daily dose of elder}

Elder flowers are generally regarded as safe (Ulbricht et al. 2014). Consumption of uncooked elder berries has been associated with poisoning and hospitalization in USA (Control 1984), therefore, their cooking are recommended to release the poisoning compounds. The internal daily dose of elder flowers is about $10-15 \mathrm{~g}$ in three divided doses. $1.5-3 \mathrm{~mL}$ fluid elder extract $(1: 1 \mathrm{~g} / \mathrm{mL})$, 2-3.75 g soft elder extract (5:1) in three divided doses are recommended to use internally (Bradley 1992). The dried elder flowers are standardized on the base of total flavonoids (calculated as isoquercetin), which must contain not less than $0.8 \%$. In other text, 3-5 g dried flowers as infusion, or $3-5 \mathrm{~mL}$ liquid extract (1:1 ethanol $25 \%)$, and $10-25 \mathrm{~mL}$ elder flower tincture (1:5 ethanol $25 \%$ ) are recommended to use orally, three times a day without any restriction on duration of use. No contraindication, warning, or interaction with other medication have been reported (Monographs 2013). Due to limited information on elder flowers, it should not be administered during the pregnancy, and lactation without medical supervision (Organization 2004). There is insufficient data for children under 18 years, pregnant and lactation women (Ulbricht et al. 2014). Elderberry or elder flower is safe, cost effective, and efficient plant for treatment and prophylaxis of influenza.

\section{Conclusion}

Several different viral agents are responsible for acute upper respiratory tract infections, which rhinoviruses or common cold viruses are responsible for upper respiratory tract infection in over $50 \%$ of cases. The outbreak of influenza virus A or B occurs during each winter. Influenza virus type A occurs as pandemic or epidemics more frequently and is more dangerous than type B. Influenza virus type $\mathrm{B}$ is less severe and in children has the clinical symptoms similar to influenza A. Influenza viral infection occur in every age, but its rate is high among the children. Young children under 2 years old or elder have high mortality rates (Moghadami 2017). Elder berries and elder flowers were well tolerated and safe. The use of elder flowers for treatment of colds, and flu has been confirmed by German commission E (Blumenthal et al. 2000), while the clinical trials confirmed the efficacy of elder berries in treatment of clinical symptoms of flu and common cold (Zakay-Rones et al. 1995, 2004; Tiralongo et al. 2016; Kong 2009). Elder berries extract was found to be more effective against influenza A virus than influenza B type (Zakay-Rones et al. 2004). Elderberry extract significantly reduced the cold duration and its severity in patients with flu and flu like diseases. The clinical symptoms of flu such as fever, muscle aches, cough, nasal congestion, mucus discharge, and headache significantly improved after administration of elderberry extract. The occurrence of flu and cold and their severity significantly decreased in air passengers consuming the elder berries lozenges. Elder flowers or elder berries are rich of flavonoids, anthocyanins, polyphenols, pectic polysaccharides and lectins, which are responsible for its efficacy in management of flu and common cold. Although, the clinical studies confirmed the efficacy of elder berries extract in treatment of flu and colds, there is no clinical study for the efficacy of elder flowers in management of flu or common cold. Therefore, designing the clinical trials for evaluating the efficacy of elder flowers in comparison with elder berries or current chemical cold syrups is recommended. Elderberry extracts in combination with vitamin $\mathrm{C}$ and zinc may shorten the duration of cold and relief its severity. Therefore, the combination of elder flowers, elder berries, vitamin $\mathrm{C}$ and Zinc can be evaluated in regard of efficacy or safety on patients with cold or flu. The efficacy and safety of this combination can be the subject of other clinical trials in HIV-positive patients due to immune modulatory effects of elders. 
Acknowledgements The authors are thankful from TabibDaru Pharmaceutical Company, Kashan, Iran. This paper is the outcomes of an in-house non-supported study.

\section{Compliance with ethical standards}

Ethical statement This article does not contain any studies with human participants or animals performed by any of the authors.

Conflict of interest Mohaddese Mahboubi declares no conflict of interest.

\section{References}

Atkinson MD, Atkinson E (2002) Sambucus nigra L. J Ecol 90(5):895-923. https://doi.org/10.1046/j.1365-2745.2002.00698 . $\mathrm{x}$

Badescu M, Badulescu O, Badescu L, Ciocoiu M (2015) Effects of Sambucus nigra and Aronia melanocarpa extracts on immune system disorders within diabetes mellitus. Pharmaceut Biol 53(4):533-539. https://doi.org/10.3109/13880209.2014.931441

Barak V, Halperin T, Kalickman I (2001) The effect of Sambucol, a black elderberry-based, natural product, on the production of human cytokines: I. Inflammatory cytokines. Eur Cytok Netw 12(2):290-296

Blumenthal MJIMC (1998) The Complete German Commission E Monographs. American Botanical Council, Austin

Blumenthal M, Goldberg A, Brinckmann J (2000) Herbal medicine. Expanded commission E monographs. Integrative Medicine Communications, Newton, USA

Bradley P (1992) British herbal compendium. Volume 1. A handbook of scientific information on widely used plant drugs. Companion to Volume 1 of the British Herbal Pharmacopoeia, vol 1. BHMA, Bristol

British Herbal Pharmacopoeia B (1966) Britich Herbal Medicine Asotiation. BHMA, Bristol, UK

Brønnum-Hansen K, Honoré Hansen S (1983) High-performance liquid chromatographic separation of anthocyanins of Sambucus nigra L. J Chromatogr A 262:385-392. https://doi.org/10.1016/ S0021-9673(01)88125-5

Burge E, Mumcuoglu M, Simmons T (1999) The effect of sambucol on flu-like symptoms in chimpanzees: prophylactic and symptom-dependent treatment. Int Zoo News 46:16-19

Castillo-Maldonado I, Moreno-Altamirano MMB, Serrano-Gallardo LB (2017) Anti-dengue serotype-2 activity effect of Sambucus nigra leaves-and flowers-derived compounds. Virol Res Rev $1(3): 1-5$

Chen C, Zuckerman DM, Brantley S, Sharpe M, Childress K, Hoiczyk E, Pendleton AR (2014) Sambucus nigra extracts inhibit infectious bronchitis virus at an early point during replication. BMC Veterin Res 10(1):24. https://doi.org/10.1186/1746-6148-10-24

Control CfD (1984) Poisoning from elderberry juice-California. MMWR, vol 33. Government Printing Office (GPO), Washington

da Silva RFR, Barreira JCM, Heleno SA, Barros L, Calhelha RC, Ferreira ICFR (2019) Anthocyanin profile of elderberry juice: a natural-based bioactive colouring ingredient with potential food application. Molecules 24(13):2359. https://doi.org/10.3390/ molecules 24132359

Duymus Agalar H, Demirci B, Baser KHC (2014) The volatile compounds of Elderberries (Sambucus nigra L.). Nat Volat Essen Oils 1:51-54
Fendrick AM, Monto AS, Nightengale B, Sarnes M (2003) The economic burden of non-influenza-related viral respiratory tract infection in the United States. J Arch Intern Med 163(4):487-494

Girard MP, Cherian T, Pervikov Y, Kieny MP (2005) A review of vaccine research and development: human acute respiratory infections. Vaccine 23(50):5708-5724. https://doi.org/10.1016/j.vacci ne.2005.07.046

Hänsel R, Rimpler H, Keller K, Schneider G, Abel G, Bader G, Baumann T, Bertram B, Beyer G, Bodesheim U (1994) Hagers Handbuch der Pharmazeutischen Praxis: Drogen PZ. Springer, Berlin

Hensel A, Deters AM, Muller G, Stark T, Wittschier N, Hofmann T (2007) Occurrence of N-phenylpropenoyl-L-amino acid amides in different herbal drugs and their influence on human keratinocytes, on human liver cells and on adhesion of Helicobacter pylori to the human stomach. Planta Med 73(2):142-150. https://doi. org/10.1055/s-2006-957079

Ho GTT (2017) Bioactive compounds in flowers and fruits of Sambucus nigra L. University of Oslo, Norway

Janeway CAJ, Travers P, Walport M, Shlomchik MJ (2001) Immunobiology: the immune system in health and disease. Garland Science, New York

Kaack K (2008) Aroma composition and sensory quality of fruit juices processed from cultivars of elderberry (Sambucus nigra L.). Eur Food Res Technol 227(1):45-56. https://doi.org/10.1007/s0021 7-007-0691-z

Kaack K, Austed T (1998) Interaction of vitamin C and flavonoids in elderberry (Sambucus nigra L.) during juice processing. Plant Foods Hum Nutr 52(3):187-198. https://doi.org/10.1023/a:10080 69422202

Kaur K, Kaur R, Kaur H, Kaur S (2014) A comprehensive review: Sambucus nigra. Linn Biolife 2(3):941-948

Knudsen BF, Kaack KV (2015) A review of human health and disease claims for elderberry (Sambucus nigra) fruit. Acta Hort 1061:121-131. https://doi.org/10.17660/ActaHortic.2015.1061.12

Kong F-k (2009) Pilot clinical study on a proprietary elderberry extract: efficacy in addressing influenza symptoms. J Pharmacol Pharmacokinet 5:32-43

Konlee M (1998) A new triple combination therapy. J Positive Health News 17:12-14

Krawitz C, Mraheil MA, Stein M, Imirzalioglu C, Domann E, Pleschka $S$, Hain T (2011) Inhibitory activity of a standardized elderberry liquid extract against clinically-relevant human respiratory bacterial pathogens and influenza A and B viruses. BMC Complem Altern Med 11:16. https://doi.org/10.1186/1472-6882-11-16

Mahmood N, Pizza C, Aquino R, De Tommasi N, Piacente S, Colman S, Burke A, Hay AJ (1993) Inhibition of HIV infection by flavanoids. Antiviral Res 22(2-3):189-199. https://doi. org/10.1016/0166-3542(93)90095-Z

Mateus N, Oliveira J, Haettich-Motta M, de Freitas V (2004) New family of bluish pyranoanthocyanins. J Biomed Biotechnol 5:299 305. https://doi.org/10.1155/S1110724304404033

Moghadami M (2017) A narrative review of influenza: a seasonal and pandemic disease. Iran J Med Sci 42(1):2-13

Monographs E (2013) Sambuci flos-elder flower. European Scientific Cooperative on Phytotherapy (ESCOP), Notaries House, Chapel Street, Exeter EX1 1EZ, UK

Morag A, Mumcuoglu M, Baybikov T, Schelsinger M, Zakay-Rones Z (1997) Inhibition of sensitive and acyclovir-resistant HSV-1 strains by an elderberry extract in vitro. J Z Phytother 25:97-98

Mousa HA-L (2017) Prevention and treatment of influenza, influenzalike illness, and common cold by herbal, complementary, and natural therapies. J Evid Based Complem Altern Med 22(1):166-174. https://doi.org/10.1177/2156587216641831

Nagai T, Miyaichi Y, Tomimori T, Suzuki Y, Yamada H (1992) In vivo anti-influenza virus activity of plant flavonoids possessing 
inhibitory activity for influenza virus sialidase. Antiviral Res 19(3):207-217. https://doi.org/10.1016/0166-3542(92)90080-o

Organization WH (2004) WHO monographs on selected medicinal plants, Flos Sambuci, vol 2. WHO, Geneva

Porter RS, Bode RF (2017) A review of the antiviral properties of black elder (Sambucus nigra L.) Products. Phytother Res PTR 31(4):533-554. https://doi.org/10.1002/ptr.5782

Rodrigues S, de Brito ES, de Oliveira Silva E (2018) Elderberry-Sambucus nigra L. In: Exotic Fruits. Elsevier, pp 181-185

Roschek B, Fink RC, McMichael MD, Li D, Alberte RS (2009) Elderberry flavonoids bind to and prevent $\mathrm{H} 1 \mathrm{~N} 1$ infection in vitro. Phytochemistry 70(10):1255-1261. https://doi.org/10.1016/j. phytochem.2009.06.003

Sahpira-Nahor O, Zakay-Rones Z, Mumcuoglu M (1995) The effects of Sambucol ${ }^{\circledR}$ on HIV infection in vitro. Ann Israel Congress Microbiol. Feb 6-7

Senica M, Stampar F, Veberic R, Mikulic-Petkovsek M (2017) The higher the better? Differences in phenolics and cyanogenic glycosides in Sambucus nigra leaves, flowers and berries from different altitudes. J Sci Food Agric 97(8):2623-2632. https://doi. org/10.1002/jsfa. 8085

Serkedjieva J, Manolova N, Zgórniak-Nowosielska I, Zawilińska B, Grzybek J (1990) Antiviral activity of the infusion (SHS-174) from flowers of Sambucus nigra L., aerial parts of Hypericum perforatum L., and roots of Saponaria officinalis L. against influenza and herpes simplex viruses. Phytother Res 4(3):97-100. https:// doi.org/10.1002/ptr.2650040305

Stoilova I, Wilker M, Stoyanova A, Krastanov A, Stanchev V (2007) Antioxidant activity of extract from elder flower (Sambucus nigra L.). Herba Polonica 53:45-54

Tiralongo E, Wee SS, Lea RA (2016) Elderberry supplementation reduces cold duration and symptoms in air-travellers: a randomized. Double-blind placebo-controlled clinical trial. Nutrients 8(4):182. https://doi.org/10.3390/nu8040182

Troy NM, Bosco A (2016) Respiratory viral infections and host responses; insights from genomics. Respir Res 17(1):156. https ://doi.org/10.1186/s12931-016-0474-9

Ueno K, Wang ZH, Hanamure Y, Yoshitsugu M, Fukuda K, Furuta S, Uehara F, Ohyama M (1997) Reduced sialylation of glycoproteins in nasal glands of patients with chronic sinusitis. Acta Otolaryngol 117(3):420-423. https://doi.org/10.3109/00016489709113415
Ulbricht C, Basch E, Cheung L, Goldberg H, Hammerness P, Isaac R, Khalsa KPS, Romm A, Rychlik I, Varghese M, Weissner W, Windsor RC, Wortley J (2014) An evidence-based systematic review of elderberry and elderflower (Sambucus nigra) by the natural standard research collaboration. J Dietary Supplem 11(1):80-120. https://doi.org/10.3109/19390211.2013.859852

Uncini Manganelli RE, Zaccaro L, Tomei PE (2005) Antiviral activity in vitro of Urtica dioica L., Parietaria diffusa M. and Sambucus nigra L. J Ethnopharmacol 98(3):323-327. https://doi. org/10.1016/j.jep.2005.01.021

Viapiana A, Wesolowski M (2017) The phenolic contents and antioxidant activities of infusions of Sambucus nigra L. Plant Foods Hum Nutr 72(1):82-87. https://doi.org/10.1007/s11130-016-0594-x

Vlachojannis JE, Cameron M, Chrubasik S (2010) A systematic review on the Sambuci fructus effect and efficacy profiles. Phytother Res PTR 24(1):1-8. https://doi.org/10.1002/ptr.2729

Wang H, Nair MG, Strasburg GM, Chang YC, Booren AM, Gray JI, DeWitt DL (1999) Antioxidant and antiinflammatory activities of anthocyanins and their aglycon, cyanidin, from tart cherries. J Nat Prod 62(2):294-296. https://doi.org/10.1021/np980501m

Wichtl M, Bisset N (1994) Herbal drugs and phytopharmaceuticals stuttgart, 3rd edn. Medpharm, Medpharm

Zakay-Rones Z, Varsano N, Zlotnik M, Manor O, Regev L, Schlesinger M, Mumcuoglu M (1995) Inhibition of several strains of influenza virus in vitro and reduction of symptoms by an elderberry extract (Sambucus nigra L.) during an outbreak of influenza B Panama. J Altern Complement Med 1(4):361-369. https://doi.org/10.1089/ acm.1995.1.361

Zakay-Rones Z, Thom E, Wollan T, Wadstein J (2004) Randomized study of the efficacy and safety of oral elderberry extract in the treatment of influenza A and B virus infections. J Int Med Res 32(2):132-140. https://doi.org/10.1177/147323000403200205

Publisher's Note Springer Nature remains neutral with regard to jurisdictional claims in published maps and institutional affiliations. 